\title{
Syntheses of Beltlike Polycyclodiynes Intercalated with Triosmium Carbonyl Clusters
}

\author{
Wen-Yann Yeh* and Tsun-Wei Shiue \\ Department of Chemistry, National Sun Yat-Sen University, Kaohsiung, Taiwan 804 \\ Shie-Ming Peng and Gene-Hsiang Lee \\ Department of Chemistry, National Taiwan University, Taipei, Taiwan 106
}

Received March 10, 2003

\begin{abstract}
The bis(cyclodiyne) complex $\mathrm{Os}_{3}(\mathrm{CO})_{8}\left(\mu_{3}-\eta^{2}-\mathrm{C}_{14} \mathrm{H}_{20}\right)_{2}(4)$ has been prepared by treating $\mathrm{Os}_{3}-$ $(\mathrm{CO})_{10}\left(\mu_{3}-\eta^{2}-\mathrm{C}_{14} \mathrm{H}_{20}\right)(\mathbf{1})$ with $\mathrm{Me}_{3} \mathrm{NO}$ in the presence of cyclotetradeca-1,8-diyne $\left(\mathrm{C}_{14} \mathrm{H}_{20}\right)$ ligand. Thermolysis of 4 leads to the osmacycl opentadiene complex $\mathrm{Os}_{3}(\mathrm{CO})_{9}\left(\mu-\eta^{4}-\left(\mathrm{C}_{14} \mathrm{H}_{20}\right)_{2}\right)$ (3). The tris(cyclodiyne) complex $\left(\mathrm{Os}_{3}(\mathrm{CO})_{8}\right)_{2}\left(\mu_{3}, \mu_{3}-\eta^{2}, \eta^{2}-\mathrm{C}_{14} \mathrm{H}_{20}\right)\left(\mu_{3}-\eta^{2}-\mathrm{C}_{14} \mathrm{H}_{20}\right)_{2}(5)$ is obtained from the reaction of $\left(\mathrm{Os}_{3}(\mathrm{CO})_{10}\right)_{2}\left(\mu_{3}, \mu_{3}-\eta^{2}, \eta^{2}-\mathrm{C}_{14} \mathrm{H}_{20}\right)$ (2) with $\mathrm{Me} \mathrm{NO}_{3}$ and $\mathrm{C}_{14} \mathrm{H}_{20}$, while photoirradiation of $\mathbf{2}$ and $\mathrm{C}_{14} \mathrm{H}_{20}$ affords the bis(osmacyclopentadiene) complex $\left(\mathrm{Os}_{3}(\mathrm{CO})_{9}\right)_{2}-$ $\left(\mu, \mu-\eta,{ }^{4} \eta^{4}-\left(\mathrm{C}_{14} \mathrm{H}_{20}\right)_{3}\right)(\mathbf{6})$. Co-irradiation of $\mathbf{3}$ and $\mathbf{1}$ also produces $\mathbf{6}$. Compounds $\mathbf{3}, \mathbf{4}, \mathbf{5}$, and $\mathbf{6}$ can be viewed as cluster-intercalated, beltlike polycyclodiynes. The structures of $\mathbf{4}$ and $\mathbf{6}$ (two isomers) have been determined by an X-ray diffraction study.
\end{abstract}

\section{Introduction}

Cyclic dialkynes (or cyclodiynes) ${ }^{1}$ are versatile starting materials for the synthesis of superphanes and cage compounds. ${ }^{2}$ In addition, interest has been stimulated by the potential for these molecules to serve as bridging units between homo- or heterometallic centers in organometallic compounds. ${ }^{3}$ Recently, constructing higher nuclearity clusters with well-defined dimensions provides a new field of chemistry with prospective application in areas including molecular recognition and nanotechnology. ${ }^{4}$ We have prepared the triosmium cyclotetradeca-1,8-diyne $\left(\mathrm{C}_{14} \mathrm{H}_{20}\right)$ complexes $\mathrm{Os}_{3}(\mathrm{CO})_{10}\left(\mu_{3}-\eta^{2}-\right.$ $\left.\mathrm{C}_{14} \mathrm{H}_{20}\right)(\mathbf{1}),\left(\mathrm{Os}_{3}(\mathrm{CO})_{10}\right)_{2}\left(u_{3}, \mu_{3}-\eta^{2}, \eta^{2}-\mathrm{C}_{14} \mathrm{H}_{20}\right)(\mathbf{2})$, and $\mathrm{Os}_{3^{-}}$ $(\mathrm{CO})_{9}\left(\mu-\eta^{4}-\left(\mathrm{C}_{14} \mathrm{H}_{20}\right)_{2}\right)(\mathbf{3}) .{ }^{5}$ Since compounds $\mathbf{1}-\mathbf{3}$ contain

(1) (a) Nakagawa, M. In Topics in Nonbenzenoid Aromatic Chemistry; Hirokawa: Tokyo, 1973; Vol. 1. (b) Sondheimer, F. Acc. Chem. Res. 1972, 5, 81. (c) Gleiter, R.; Schäfer, W. Acc. Chem. Res. 1990, 23, 369. (d) Youngs, W.J .; Tessier, C. A.; Bradshaw, J . D. Chem. Rev. 1999, 99, 3153.

(2) (a) Vögtle, F. Cyclophane Chemistry: Synthesis, Structures and Reactivity; Wiley: Chichester, U.K., 1993. (b) Cram, D. J .; Cram, J . M. Container Molecules and Their Guests; The Royal Society of Chemistry: London, 1994. (c) Gleiter, R.; Merger, M. Angew. Chem., Int. Ed. Engl. 1997, 36, 2426. (d) King, R. B.; Efraty, A. J . Am. Chem. Soc. 1970, 92, 6071; 1972, 94, 3021. (e) King, R. B.; Ackermann, M. N. J. Organomet. Chem. 1974, 67, 431. (f) Adams, C. M.; Holt, E. M. Organometallics 1990, 9, 980.

(3) (a) Rausch, B.J .; Gleiter, R.; Rominger, F. J . Chem. Soc., Dalton Trans. 2002, 2219. (b) Hsu, M.-A.; Yeh, W.-Y.; Lee, G.-H.; Peng, S.-M. J . Organomet. Chem. 1999, 588, 32. (c) Yeh, W.-Y.; Hsu, M.-A.; Peng, S.-M.; Lee, G.-H. Inorg. Chim. Acta 1999, 294, 232.

(4) (a) Drexler, K. E. Molecular Machinery, Manufacturing, and Computation; Wiley: New York, 1992. (b) Onaka, S.; Otsuka, M. Chem Lett. 1995, 269. (c) Shriver, D. F.; Kaesz, H. D.; Adams, R. D. The Chemistry of Metal Cluster Complexes; VCH: New York, 1990. (d) Braunstein, P.; Oro, L. A.; Raithby, P. R. Metal Clusters in Chemistry; Wiley-VCH: Weinheim, Germany, 1999. (e) Yeh, W.-Y.; Wu, C.-Y.; Chiou, L.-W. Organometallics 1999, 18, 3547. (f) Lucas, N. T.; Notaras, E. G. A.; Petrie, S.; Stranger, R.; Humphrey, M. G. Organometallics 2003, 22, 708. (g) Hidai, M.; Kuwata, S.; Mizobe, Y. Acc. Chem. Res. 2000, 33, 46. (h) Leininger, S.; Oelenyuk, B.; Stang, P. J . Chem. Rev. 2000, 100, 853

(5) Yeh, W.-Y.; Hsu, M.-A.; Peng, S.-M.; Lee, G.-H. Organometallics 1999, 18, 880 . pendant alkyne ligands and/or open $\mathrm{Os}_{3}$ faces, it is promising to construct multiple cluster systems by using these complexes as building blocks. Now we report the syntheses of the unprecedented $\mathrm{Os}_{3}$-intercalated polycyclodiynes 4-6. The reaction pathways are outlined in Scheme 1.

\section{Results and Discussion}

To a mixture of $\mathbf{1}$ and $\mathrm{C}_{14} \mathrm{H}_{20}$ in dichloromethane was added 2 equiv of $\mathrm{Me}_{3} \mathrm{NO}$ (to remove $\mathrm{CO}$ ) in $\mathrm{MeCN}$ at room temperature to generate the bis(cyclodiyne) complex $\mathrm{Os}_{3}(\mathrm{CO})_{8}\left(\mu_{3}-\eta^{2}-\mathrm{C}_{14} \mathrm{H}_{20}\right)_{2}$ (4) in $32 \%$ yield after purification by TLC and crystallization. ${ }^{6}$ Compound $\mathbf{4}$ forms an air-stable yellow crystalline solid. Thermol ysis of 4 results in coupling of the coordinated alkynes to yield 3, while heating $\mathbf{1}$ produces the hydrido allene complex $(\mu-\mathrm{H}) \mathrm{Os}_{3}(\mathrm{CO})_{9}\left(u_{3}-\eta^{3}-\mathrm{C}_{14} \mathrm{H}_{19}\right){ }^{5}$ The ORTEP diagram of $\mathbf{4}$ is shown in Figure 1 . The metal parts are based upon a triangular array of osmium atoms in which the Os(1)-Os(2) distance is significantly longer than the other two intermetallic distances. The Os(1) and Os(2) atoms are each associated with three terminal carbonyl ligands, while the Os(3) atom is linked with two. The alkyne $C(9)-C(10)$ and $C(23)-C(24)$ units are asymmetrically bonded to the osmium atoms, formally forming $\pi$ bonds to the Os(3) atom and $\sigma$ bonds to the Os(1) and Os(2) atoms. The atoms (C(9), C(10), Os(1), and Os(2)) and the atoms (C(23), C(24), Os(1), and Os(2)) are coplanar to within $0.1 \AA$, and the dihedral angle between the two planes is $108^{\circ}$. Thus, the $\left[\mathrm{C}_{4} \mathrm{Os}_{2}\right]$ fragment may also be described as a diosma-Dewar-

(6) The analogous bis(alkyne) complexes $\mathrm{Os}_{3}(\mathrm{CO})_{8}\left(\mathrm{C}_{2} \mathrm{Ph}_{2}\right)_{2}$ and $\mathrm{Os}_{3}(\mathrm{CO})_{8}\left(\mathrm{C}_{2} \mathrm{Me}_{2}\right)_{2}$ were previously prepared by a similar method. J ohnson, B. F. G.; Khattar, R.; Lahoz, F. J .; Lewis, J .; Raithby, P. R. J . Organomet. Chem. 1987, 319, C51. 


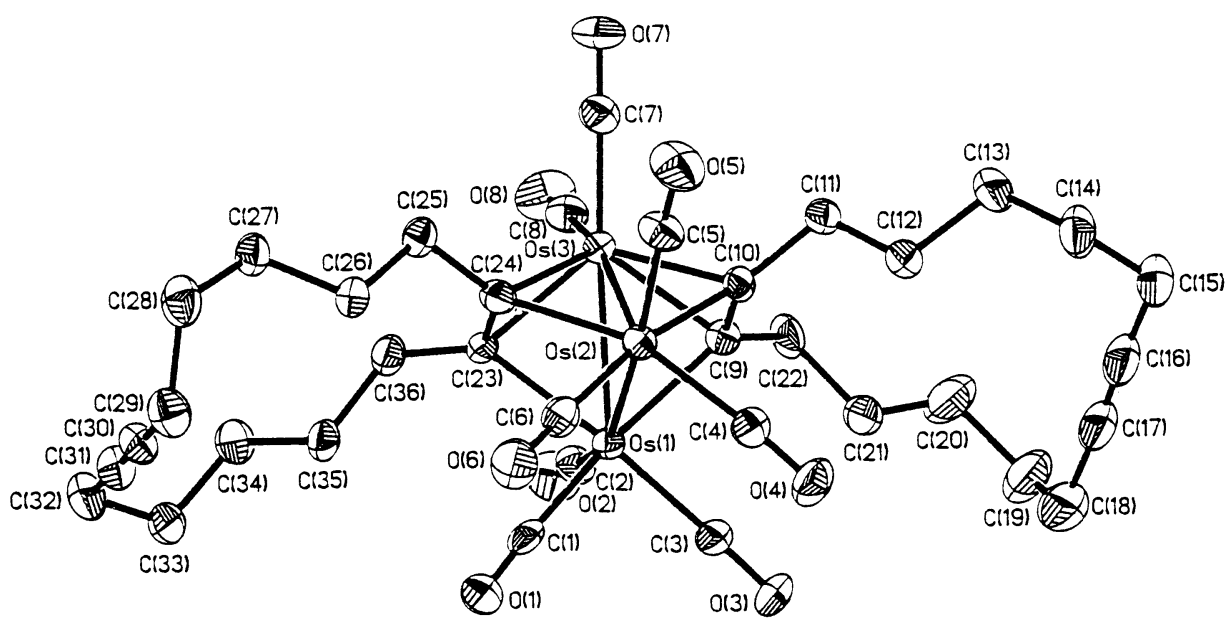

Figure 1. Molecular structure of 4. Selected bond distances $(\AA)$ : Os(1)-Os(2) $=2.7515(9)$, Os(1) $-O s(3)=2.6952(8)$, Os$(2)-\mathrm{Os}(3)=2.6942(5), \mathrm{Os}(1)-\mathrm{C}(9)=2.189(7), \mathrm{Os}(1)-\mathrm{C}(23)=2.196(7), \mathrm{Os}(2)-\mathrm{C}(24)=2.175(8), \mathrm{Os}(2)-\mathrm{C}(10)=2.201(7)$, $\mathrm{Os}(3)-\mathrm{C}(9)=2.136(8), \mathrm{Os}(3)-C(10)=2.118(7), \mathrm{Os}(3)-C(23)=2.128(7), \mathrm{Os}(3)-C(24)=2.137(7), C(9)-C(10)=1.42(1)$, $\mathrm{C}(23)-\mathrm{C}(24)=1.41(1), \mathrm{C}(16)-\mathrm{C}(17)=1.18(2), \mathrm{C}(30)-\mathrm{C}(31)=1.17(1)$. Selected bond angles (deg): Os(1) $-\mathrm{Os}(2)-\mathrm{Os}(3)=$ 59.32(2), Os(3)-Os(1)-Os(2) = 59.28(2), C(9)-Os(1)-C(23) = 100.8(3), C (9) -Os(3)-C(10) = 39.0(3), C(10)-Os(2)-C(24) $=100.7(3), C(23)-\mathrm{Os}(3)-\mathrm{C}(24)=38.5(3), C(10)-C(9)-C(22)=124.8(7), C(9)-C(10)-C(11)=126.6(6), C(24)-C(23)-$ $C(36)=127.1(7), C(23)-C(24)-C(25)=123.3(7)$.

Scheme 1

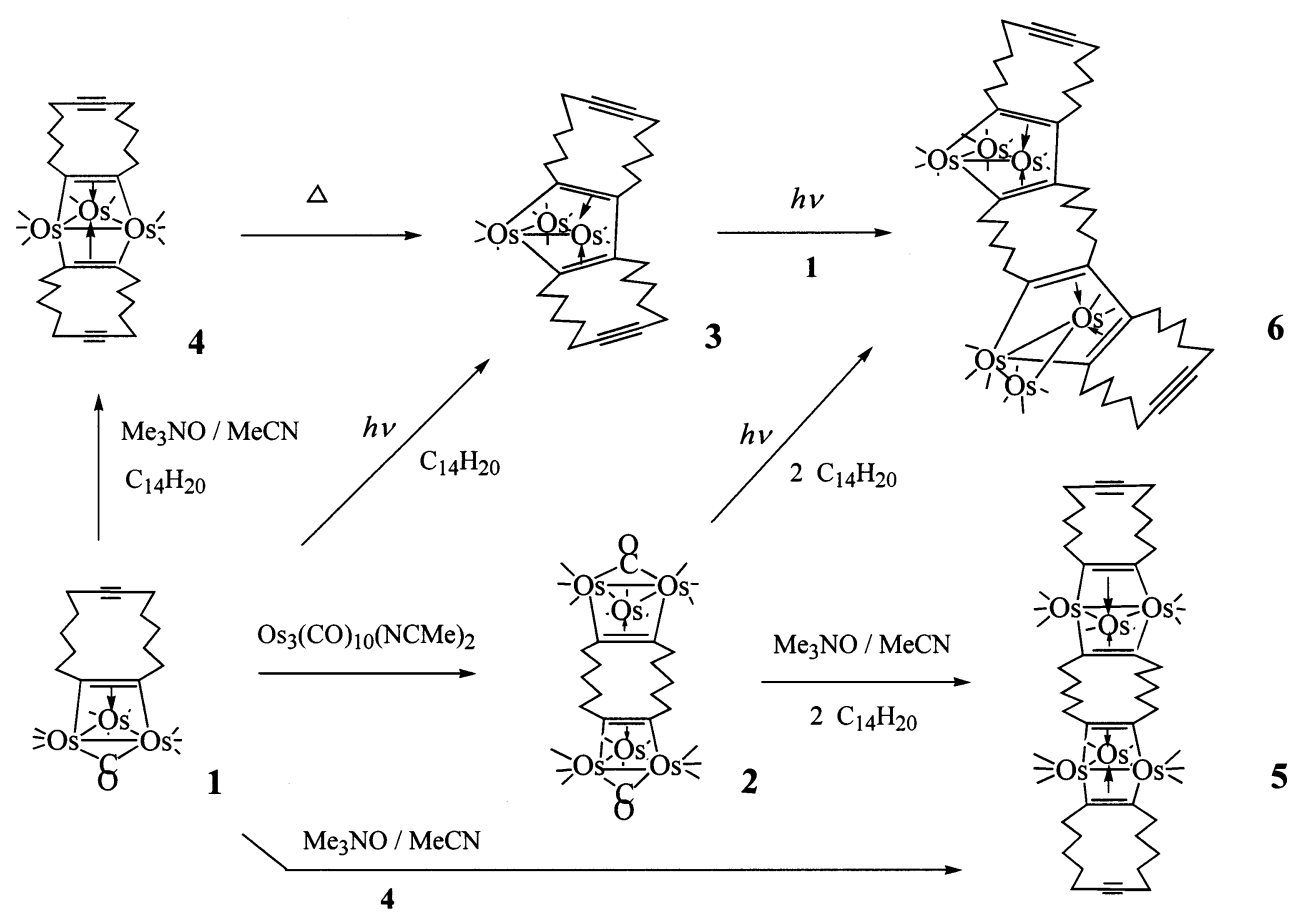

benzene ${ }^{7}$ ligand $\eta^{6}$-bonded to a $\mathrm{Os}(\mathrm{CO})_{2}$ group. Although compound $\mathbf{4}$ has no crystallographically imposed symmetry in the solid state, it exhibits the expected idealized $\mathrm{C}_{2 \mathrm{v}}$ symmetry in solution, such that the ${ }^{13} \mathrm{C}$ NMR spectrum displays three resonance signals in a 1:2:1 ratio for the eight carbonyl carbons and seven resonance signals for the 28 ring carbons. The coordinated and free $\mathrm{C} \equiv \mathrm{C}$ carbon resonances appearing at $\delta 167.2$ and 80.5 are comparable with those recorded for $\mathbf{1}$. The methylene carbon resonances in the range $\delta$ 52.6-18.1 can be assigned (Figure 2 ) on the basis of a 2D-HSQC experi-

(7) (a) Fischer, E. O.; Kreiter, C. G.; Berngruber, W. Angew. Chem., Int. Ed. Engl. 1967, 6, 634. (b) Mason, R.; Robertson, G. B.; Whimp, P. O. J . Chem. Soc. (A) 1970, 535. (c) Green, M.; Lewis, B. J . Chem. Soc., Dalton Trans. 1975, 1137. ment, ${ }^{8}$ while the methylene protons are assigned according to an $\mathrm{H}, \mathrm{H}-\mathrm{COSY}$ experiment.

Since compound 2 contains two open $\mathrm{Os}_{3}$ faces, it reacts with $\mathrm{Me}_{3} \mathrm{NO} / \mathrm{NCMe}$ and $\mathrm{C}_{14} \mathrm{H}_{20}$ to produce the double-decker tris(cyclodiyne) complex $\left(\mathrm{Os}_{3}(\mathrm{CO})_{8}\right)_{2}\left(\mu_{3}, \mu_{3^{-}}\right.$ $\left.\eta^{2}, \eta^{2}-\mathrm{C}_{14} \mathrm{H}_{20}\right)\left(\mu_{3}-\eta^{2}-\mathrm{C}_{14} \mathrm{H}_{20}\right)_{2}$ (5) in $28 \%$ yield. Alternatively, sequential treatment of $\mathbf{1}$ with $\mathrm{Me} \mathrm{e}_{3} \mathrm{NO} / \mathrm{NCM}$ and compound $\mathbf{4}$ also leads to $\mathbf{5}$. Compound $\mathbf{5}$ is analogous to 4 but with two Os $\mathrm{Os}_{3}$ spacers. Two isomers in an approximate ratio of 5:1 are present for $\mathbf{5}$, where the alkyne-osmium $\pi$ bonds can lie on the same side (syn) or opposite sides (anti) of the bridging carbocycle. The ${ }^{13} \mathrm{C}$ NMR data of $\mathbf{5}$ (the major species) are consistent

(8) Braun, S.; Kalinowski, H.-O.; Berger, S. 100 and More Basic NMR Experiments; VCH: Weinheim, Germany, 1996. 


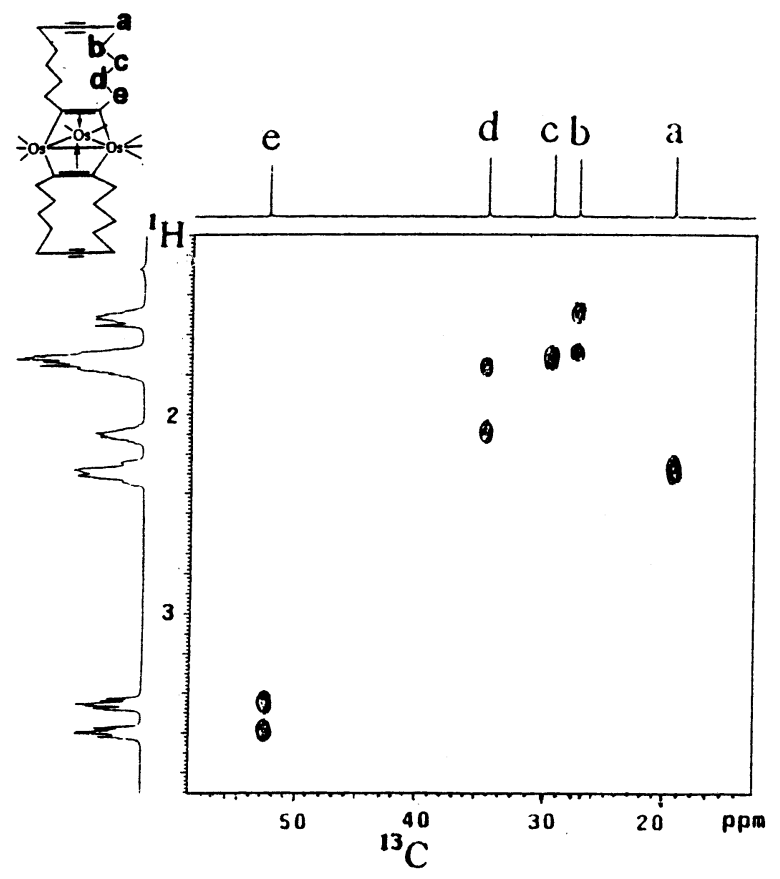

Figure 2. $2 \mathrm{D}{ }^{13} \mathrm{C} /{ }^{1} \mathrm{H}$ shift correlation spectrum of $\mathbf{4}$, taken in $\mathrm{CDCl}_{3}$ at $23{ }^{\circ} \mathrm{C}$.

with $\mathrm{C}_{2 \mathrm{~h}}$ symmetry (anti-form) or $\mathrm{C}_{2 \mathrm{v}}$ symmetry (synform) in solution, showing a signal at $\delta 80.5$ for the free alkyne carbons, two signals at $\delta 167.8$ and 165.9 for the coordinated alkyne carbons, and eight discrete signals in the range $\delta 52.6-18.2$ for the methylene carbons. Efforts to grow suitable crystals for an X-ray diffraction study failed. Since compound $\mathbf{2}$ was structurally characterized as having an anti-configuration, ${ }^{5}$ it seems reasonable to assume that the anti-form is dominant for 5 .

Compound $\mathbf{3}$ was previously obtained from photoirradiation of $\mathbf{1}$ in the presence of a $\mathrm{C}_{14} \mathrm{H}_{20}$ ligand. ${ }^{5}$ Likewise, co-irradiation of $\mathbf{1}$ and $\mathbf{3}$ produces the doubledecker bis(osmacyclopentadiene) complex $\left(\mathrm{Os}_{3}(\mathrm{CO})_{9}\right)_{2^{-}}$ $\left(\mu, \mu-\eta,{ }^{4} \eta^{4}-\left(\mathrm{C}_{14} \mathrm{H}_{20}\right)_{3}\right)(\mathbf{6})$. A convenient method to make $\mathbf{6}$ is irradiation of $\mathbf{2}$ and $\mathrm{C}_{14} \mathrm{H}_{20}$ by inserting one cyclodiyne into each $\mathrm{Os}_{3}$ framework. The IR spectra of $\mathbf{6}$ and $\mathbf{3}$ suggest similar coordination environments for the two complexes. However, four geometric isomers can result for $\mathbf{6}$, in which the two osmium atoms of the metallacycles can be cis or trans to one another, and the two osmium atoms above the metallacycles can lie on the same side (syn) or opposite sides (anti). Two major products, $\mathbf{6 a}$ and $\mathbf{6 b}$, in about equal amounts have been isolated, which present the same blue color and compatible mass, IR, and NMR data.

The ORTEP diagram of $\mathbf{6 b}$ (Figure 3 ) exhibits a transsyn configuration, where the two $\mathrm{Os}_{3}$ clusters adopt the same environment. The Os-Os distances in each cluster show substantial variation, ranging from 2.7229(6) to 2.9293(6) $\AA$. The two osmacyclopentadiene fragments form $\sigma$ bonds to Os(1) and Os(4) and $\pi$ bonds to Os(2) and $\mathrm{Os}(5)$ atoms. Each osmacyclopentadiene ring is

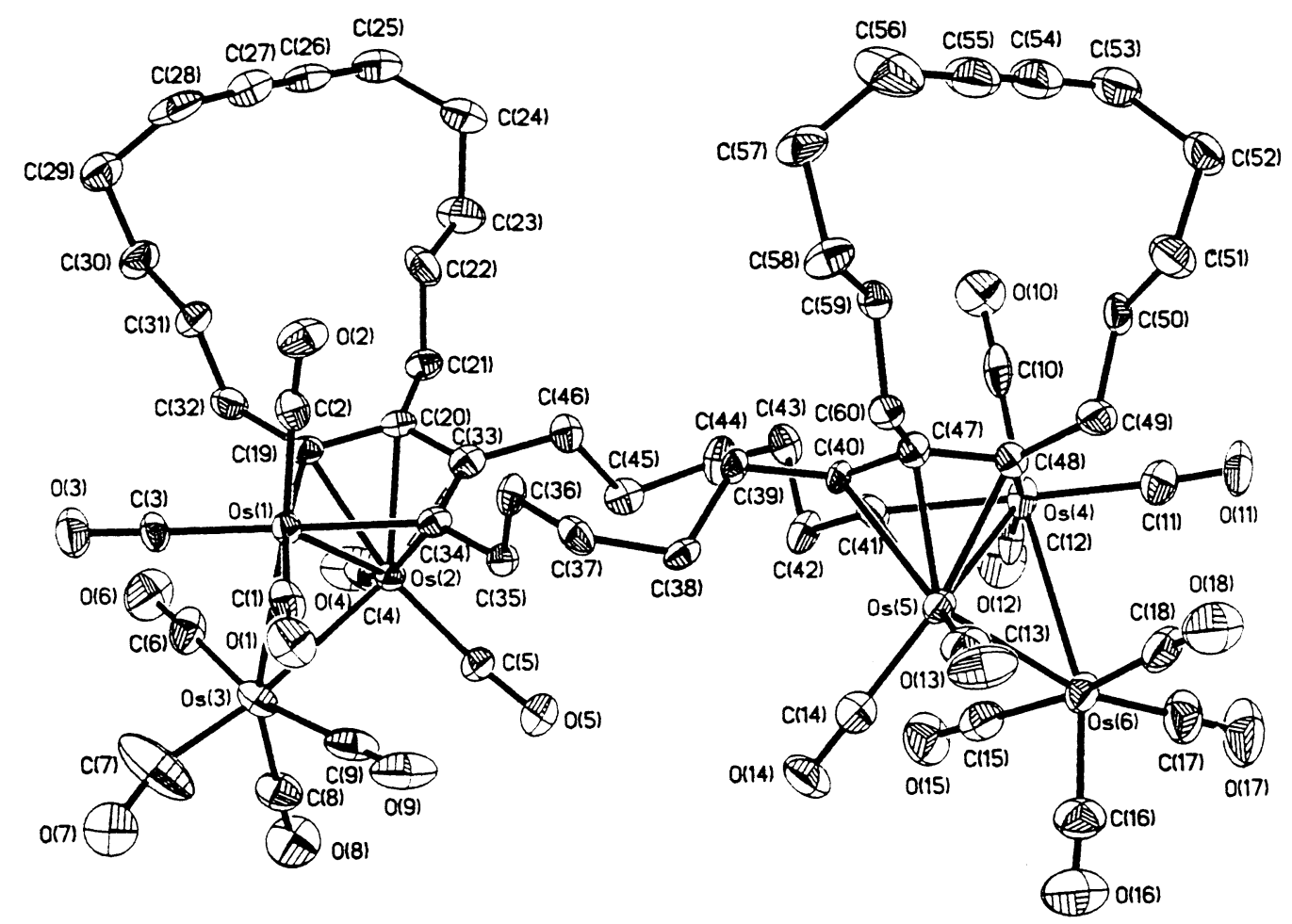

Figure 3. Molecular structure of $\mathbf{6 b}$. Selected bond distances $(\AA)$ : Os(1)-Os(2)=2.7428(5), Os(1)-Os(3) $=2.9293(6)$, $\mathrm{Os}(2)-\mathrm{Os}(3)=2.7229(6), \mathrm{Os}(4)-\mathrm{Os}(5)=2.7414(6), \mathrm{Os}(4)-\mathrm{Os}(6)=2.9254(6), \mathrm{Os}(5)-\mathrm{Os}(6)=2.7254(6), \mathrm{Os}(2)-\mathrm{C}(19)=$ 2.254(9), Os(2) $-C(20)=2.259(9), \mathrm{Os}(2)-C(33)=2.273(9), \mathrm{Os}(2)-C(34)=2.238(9), \mathrm{Os}(5)-C(40)=2.292(9), \mathrm{Os}(5)-C(41)$ $=2.255(9), \mathrm{Os}(5)-\mathrm{C}(47)=2.281(9), \mathrm{Os}(5)-\mathrm{C}(48)=2.271(9), \mathrm{Os}(1)-\mathrm{C}(19)=2.135(9), \mathrm{C}(19)-\mathrm{C}(20)=1.43(1), \mathrm{C}(20)-\mathrm{C}(33)$ $=1.46(1), \mathrm{C}(33)-\mathrm{C}(34)=1.41(1), \mathrm{Os}(1)-\mathrm{C}(34)=2.140(9), \mathrm{Os}(4)-\mathrm{C}(48)=2.137(9), \mathrm{C}(47)-\mathrm{C}(48)=1.43(1), \mathrm{C}(40)-\mathrm{C}(47)=$ 1.45(1), $C(40)-C(41)=1.43(1)$, Os(4)-C(41) = 2.159(9). Selected bond angles (deg): Os(1)-Os(2)-Os(3) $=64.82(2)$, Os(1) $-\mathrm{Os}(3)-\mathrm{Os}(2)=57.92(1), \mathrm{Os}(4)-\mathrm{Os}(5)-\mathrm{Os}(6)=64.70(2), \mathrm{Os}(4)-\mathrm{Os}(6)-\mathrm{Os}(5)=57.91(1), \mathrm{C}(20)-\mathrm{C}(19)-\mathrm{Os}(1)=116.2-$ (7), $C(19)-C(20)-C(33)=114.2(8), C(34)-C(33)-C(20)=115.5(9), C(33)-C(34)-O s(1)=116.2(7), C(19)-O s(1)-C(34)=$ 76.7(4), $C(47)-C(48)-O s(4)=116.2(6), C(40)-C(47)-C(48)=115.2(8), C(41)-C(40)-C(47)=115.2(8), C(40)-C(41)-$ Os$(4)=115.5(6), C(48)-O s(4)-C(41)=76.8(4)$. 


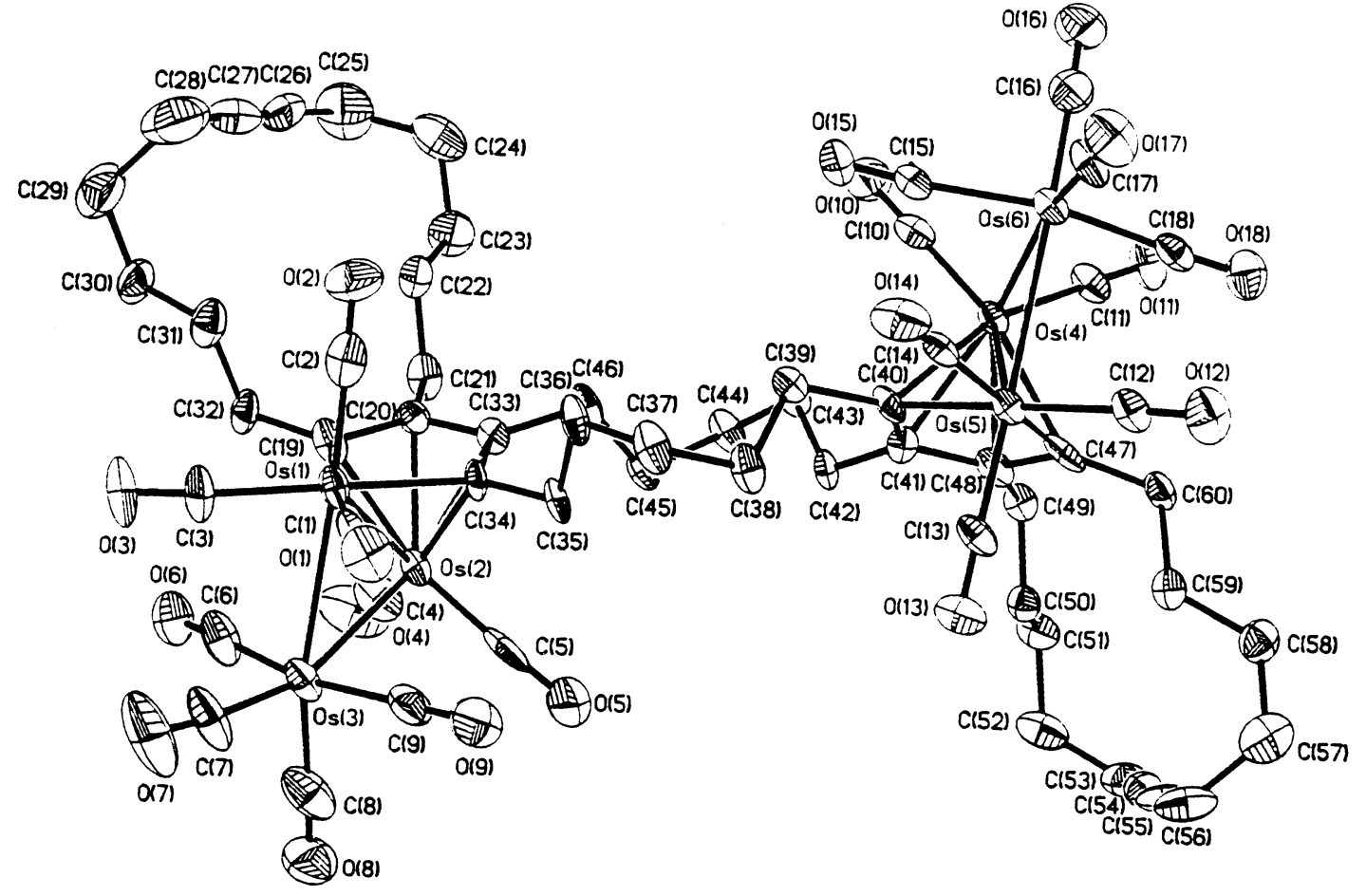

Figure 4. Molecular structure of $\mathbf{6 a}$. Selected bond distances $(\AA)$ : $\operatorname{Os}(1)-\operatorname{Os}(2)=2.7444(7), \operatorname{Os}(1)-\operatorname{Os}(3)=2.9142(7)$, $\mathrm{Os}(2)-\mathrm{Os}(3)=2.7265(6), \mathrm{Os}(4)-\mathrm{Os}(5)=2.7389(6), \mathrm{Os}(4)-\mathrm{Os}(6)=2.7128(6), \mathrm{Os}(5)-\mathrm{Os}(6)=2.9015(6), \mathrm{Os}(2)-\mathrm{C}(19)=$ $2.258(13), \mathrm{Os}(2)-\mathrm{C}(20)=2.28(1), \mathrm{Os}(2)-\mathrm{C}(33)=2.28(1), \mathrm{Os}(2)-\mathrm{C}(34)=2.24(1), \mathrm{Os}(4)-\mathrm{C}(40)=2.264(9), \mathrm{Os}(4)-\mathrm{C}(41)=$ 2.28(1), Os(4)-C(47) = 2.28(1), Os(4)-C(48)=2.291(1), Os(1)-C(19) = 2.13(1), Os(1)-C(34)=2.14(1), C(19) $-\mathrm{C}(20)=$ $1.44(1), C(20)-C(33)=1.46(2), C(33)-C(34)=1.42(1), O s(5)-C(40)=2.12(1), O s(5)-C(47)=2.13(1), C(40)-C(41)=1.45-$ (1), $C(41)-C(48)=1.42(2), C(47)-C(48)=1.46(1)$. Selected bond angles (deg): Os(1)-Os(2)-Os(3)=64.37(2), Os(1)-Os$(3)-\mathrm{Os}(2)=58.11(2), \mathrm{Os}(4)-\mathrm{Os}(5)-\mathrm{Os}(6)=57.41(2), \mathrm{Os}(4)-\mathrm{Os}(6)-\mathrm{Os}(5)=58.28(1), \mathrm{C}(20)-\mathrm{C}(19)-\mathrm{Os}(1)=116.5(8), \mathrm{C}(19)-$ $C(20)-C(33)=113.4(9), C(34)-C(33)-C(20)=116.2(9), C(33)-C(34)-O s(1)=115.2(8), C(19)-O s(1)-C(34)=77.2(4)$, $\mathrm{C}(48)-\mathrm{C}(47)-\mathrm{Os}(5)=114.6(8), \mathrm{C}(41)-\mathrm{C}(48)-\mathrm{C}(47)=116.3(9), \mathrm{C}(48)-\mathrm{C}(41)-\mathrm{C}(40)=114.4(9), \mathrm{C}(41)-\mathrm{C}(40)-\mathrm{Os}(5)=116.3-$ (8), $C(40)-O s(5)-C(47)=77.6(4)$.

nearly planar, and the interplane angle between the two rings is $54^{\circ}$, leading to a bowlike shape for the polycyclic chain. On the other hand, the molecular structure of 6a displays a cis-anti configuration. A striking feature about $\mathbf{6 a}$ is the polycyclic chain which is annealed into a helix. The crystalline material of $\mathbf{6} \mathbf{a}$ is achiral, with each unit cell containing a right- and a left-handed helical molecule. The ORTEP diagram for the lefthanded enantiomer is exhibited in Figure 4, which displays interatomic distances and angles similar to $\mathbf{6 b}$. Stereoscopic views of $\mathbf{6} \mathbf{a}$ and $\mathbf{6 b}$ are provided in Figure 5 for comparison. The remaining two isomers are probably among the several uncharacterized minor products $(<1 \%)$. We do not have mechanistic information to account for the product distribution. However, the energy-minimized structures constructed for the trans-anti and cis-syn forms appear more space-congested than the corresponding cis-anti (6a) and transsyn (6b) forms, suggesting that steric effects might play an importance role.

Compounds 3, 4, 5, and 6 are air-stable and soluble in common organic solvents. They contain two pendant alkyne groups and can be viewed as metalated polycyclodiynes with 29, 30, 46, and 44 ring atoms, respectively. The distances between the two alkynes are diverse, ranging from 8.8 to $24 \AA$ (Chart 1). The three carbocyclic rings of $\mathbf{5}$ are presumed to line up as in $\mathbf{4}$, giving an estimated alkyne-alkyne distance of $24 \AA$, while the curled bonding feature of $\mathbf{6}$ leads to shorter alkyne-alkyne spans, being $16.8 \AA$ for $\mathbf{6 a}$ and $12.4 \AA$ for $\mathbf{6 b}$.

In conclusion, the synthesis of $\mathbf{3 - 6}$ is of interest within the context of the chemistry of cyclodiynes and metallacycles and the ability of a cluster system to promote these reactions. It appears that the multicluster complexes $\left(\mathrm{C}_{14} \mathrm{H}_{20}\right)\left[\mathrm{Os}_{3}\left(\mathrm{C}_{14} \mathrm{H}_{20}\right)\right]_{n}(\mathrm{n} \geq 2)$ containing a straight or a curled metallapolycyclodiyne chain can be prepared by repeating the $\mathrm{Me}_{3} \mathrm{NO} / \mathrm{MeCN}$ treatment or photoirradiation with or without the presence of $\mathrm{C}_{14} \mathrm{H}_{20}$ ligands. Moreover, the flexibility of the terminal cycloyne units should provide the possibility of a metalinduced ring closure to form macrocyclic compounds, ${ }^{9}$ which are important topics in supramolecular chemistry. ${ }^{10} \mathrm{~F}$ urther investigation is in progress in our laboratory.

\section{Experimental Section}

General Methods. All manipulations were carried out under an atmosphere of dinitrogen with standard Schlenk techniques. ${ }^{11}$ Cycloteradeca-1,8-diyne $\left(\mathrm{C}_{14} \mathrm{H}_{20}\right)^{12}$ and $\mathrm{Os}_{3}(\mathrm{CO})_{10^{-}}$

(9) (a) Schaller, R. J .; Gleiter, R.; H ofmann, J .; Rominger, F. Angew. Chem., Int. Ed. 2002, 41, 1181. (b) Piguet, C.; Bernardinelli, G.; Hopfgartner, G. Chem. Rev. 1997, 97, 2005. (c) Song, L.-C.; Fan, H.T.; Hu, Q.-M. J . Am. Chem. Soc. 2002, 124, 4566.

(10) Steed, J. W.; Atwood, J. L. Supramol ecular Chemistry; Wiley: New York, 2000.

(11) Shriver, D. F.; Drezdzon, M. A. The Manipulation of AirSensitive Compounds, 2nd ed.; Wiley: New York, 1986. 

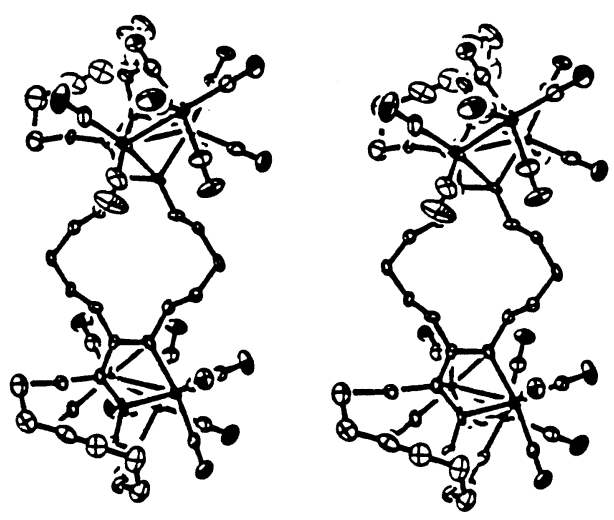

6a
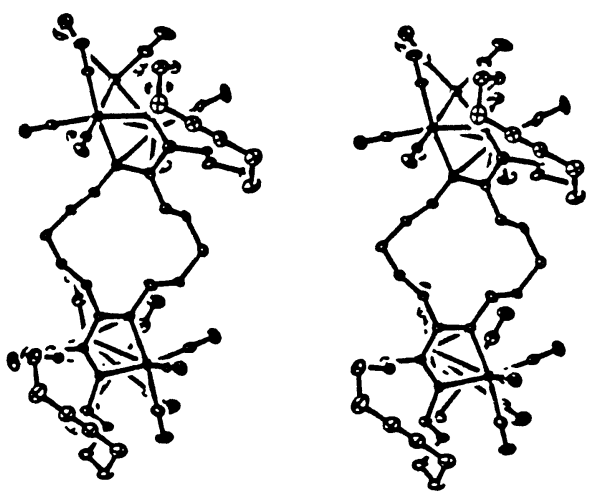

6b

Figure 5. Stereoscopic views of $\mathbf{6 a}$ and $\mathbf{6 b}$.

Table 1. Crystallographic Data for 4, 6a, and $6 b$

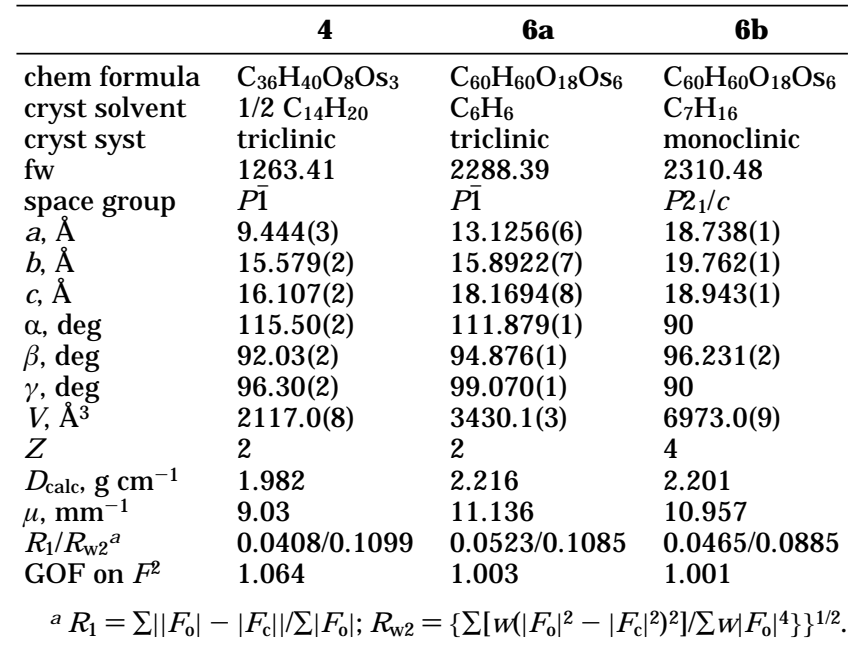

$(\mathrm{NCMe})_{2}^{13}$ were prepared by literature methods. Anhydrous trimethylamine $\mathrm{N}$-oxide was obtained from $\mathrm{Me}_{3} \mathrm{NO} \cdot 2 \mathrm{H}_{2} \mathrm{O}$ (98\%, Aldrich) by sublimation at $110{ }^{\circ} \mathrm{C}$ under vacuum. Solvents were dried over appropriate reagents under dinitrogen and distilled immediately before use. ${ }^{14}$ Preparative thinlayer chromatographic (TLC) plates were prepared from silica gel (Merck). ${ }^{1 \mathrm{H}}$ and ${ }^{13} \mathrm{C}$ NMR spectra were obtained on a Varian U nity I NOVA-500 spectrometer at 500 and $125.7 \mathrm{MHz}$,

(12) Gleiter, R.; Merger, R.; Treptow, B.; Wittwer, W.; Pflästerer, G. Synthesis 1993, 558.

(13) Braga, D.: Grepioni, F.; Parisini, E.; ohnson, B. F. G.; Martin C. M.; Nairn, J. G. M.; Lewis, J .; Martinelli, M. J . Chem. Soc., Dalton Trans. 1993, 1891.

(14) Perrin, D. D.; Armarego, W. L. F. Purification of Laboratory Chemicals, 3rd ed.; Pergamon Press: Oxford, U.K., 1988. respectively. Fast-atom-bombardment ( $F A B)$ mass spectra were recorded on a J EOL J MS-SX102A mass spectrometer. Elemental analyses were performed at the National Science Council Regional Instrumentation Center at National ChenKung University, Tainan, Taiwan.

Preparation of 4. Compound 1 (50 mg, $0.048 \mathrm{mmol}$ ) and $\mathrm{C}_{14} \mathrm{H}_{20}$ (23 mg, $\left.0.12 \mathrm{mmol}\right)$ were dissolved in $\mathrm{CH}_{2} \mathrm{Cl}_{2}(25 \mathrm{~mL})$, and $\mathrm{Me}_{3} \mathrm{NO}$ ( $\left.7 \mathrm{mg}, 0.096 \mathrm{mmol}\right)$ dissolved in $\mathrm{MeCN}(8 \mathrm{~mL})$ was added dropwise over $1 \mathrm{~h}$. The resulting solution was stirred at ambient temperature for $3.5 \mathrm{~h}$. The solvents were removed on a rotary evaporator, and the residue was subjected to TLC, with $\mathrm{CH}_{2} \mathrm{Cl}_{2} / \mathrm{n}$-hexane as eluant (1:9, v/v). Crystallization of the material forming the major yellow band from n-heptane at $-15{ }^{\circ} \mathrm{C}$ afforded orange-yellow needle crystals of $\mathrm{Os}_{3}(\mathrm{CO})_{8}\left(\mu_{3}-\eta^{2}-\mathrm{C}_{14} \mathrm{H}_{20}\right)_{2}$ (4; $\left.18 \mathrm{mg}, 32 \%\right)$. Mass spectrum (FAB): $\mathrm{m} / \mathrm{z} 1170\left(\mathrm{M}^{+},{ }^{190} \mathrm{Os}\right)$. IR $\left(\mathrm{CH}_{2} \mathrm{Cl}_{2}, v \mathrm{CO}\right): 2080(\mathrm{~m}), 2040$ (s), 2016 (sh), 2000 (vs), 1970 (m), 1936 (w) cm-1. ${ }^{1} \mathrm{H}$ NMR $\left(\mathrm{CDCl}_{3}, 23{ }^{\circ} \mathrm{C}\right): \delta 3.59,3.46,2.28,2.11,1.72,1.51\left(\mathrm{~m}, \mathrm{CH}_{2}\right)$. ${ }^{13} \mathrm{C}\left\{{ }^{1} \mathrm{H}\right\} \mathrm{NMR}\left(\mathrm{CDCl}_{3}, 23{ }^{\circ} \mathrm{C}\right): \delta 181.2(\mathrm{CO}), 178.8(\mathrm{CO}), 167.2$ ( $\mathrm{C} \equiv \mathrm{C}-\mathrm{Os}$ ), 166.0 (CO), 80.5 (free $\mathrm{C} \equiv \mathrm{C}$ ), 52.6, 34.1, 28.6, 26.4, $18.1\left(\mathrm{CH}_{2}\right)$. Anal. Calcd for $\mathrm{C}_{36} \mathrm{H}_{40} \mathrm{O}_{8} \mathrm{Os}_{3}$ : C, 36.90; $\mathrm{H}, 3.40$. Found: C, 36.71; H, 3.49.

Preparation of $\mathbf{5}$ from $\mathbf{2}$ and $\mathbf{C}_{\mathbf{1 4}} \mathbf{H}_{\mathbf{2 0}}$. Compound $\mathbf{2}$ ( $10 \mathrm{mg}$, $0.005 \mathrm{mmol})$ and $\mathrm{C}_{14} \mathrm{H}_{20}(8 \mathrm{mg}, 0.04 \mathrm{mmol})$ were dissolved in $\mathrm{CH}_{2} \mathrm{Cl}_{2}(5 \mathrm{~mL})$, and a solution of $\mathrm{Me}_{3} \mathrm{NO}(2 \mathrm{mg}, 0.03 \mathrm{mmol})$ in $\mathrm{MeCN}(2 \mathrm{~mL}$ ) was added via a syringe over $1 \mathrm{~h}$. The resulting mixture was stirred for another $3 \mathrm{~h}$ at ambient temperature. The solvents were removed on a rotary evaporator, and the residue was subjected to TLC, with $\mathrm{CH}_{2} \mathrm{Cl}_{2} / \mathrm{n}$-hexane as eluant $(2: 3, v / v)$. The first yell ow band was isolated and characterized as $\left(\mathrm{Os}_{3}(\mathrm{CO})_{8}\right)_{2}\left(\mu_{3}, \mu_{3}-\eta^{2}, \eta^{2}-\mathrm{C}_{14} \mathrm{H}_{20}\right)\left(\mu_{3}-\eta^{2}-\mathrm{C}_{14} \mathrm{H}_{20}\right)_{2}(5 ; 3 \mathrm{mg}, 28 \%)$. Mass spectrum (FAB): $\mathrm{m} / \mathrm{z} 2152\left(\mathrm{M}^{+},{ }^{190} \mathrm{Os}\right)$. IR $\left(\mathrm{CH}_{2} \mathrm{Cl}_{2}\right.$, $v \mathrm{CO}): 2080$ (m), 2036 (s), 2016 (sh), 1998 (vs), 1968 (m), 1934 (w) $\mathrm{cm}^{-1} .{ }^{1} \mathrm{H} N M R\left(\mathrm{CDCl}_{3}, 23{ }^{\circ} \mathrm{C}\right): \delta 3.71(\mathrm{~m}, 4 \mathrm{H}), 3.61(\mathrm{~m}$, $4 \mathrm{H}), 3.39(\mathrm{~m}, 8 \mathrm{H}), 2.29(\mathrm{~m}, 8 \mathrm{H}), 2.13(\mathrm{~m}, 4 \mathrm{H}), 1.94(\mathrm{~m}, 4 \mathrm{H})$, $1.77(\mathrm{~m}, 24 \mathrm{H}), 1.50(\mathrm{~m}, 4 \mathrm{H}) \cdot{ }^{13} \mathrm{C}\left\{{ }^{1} \mathrm{H}\right\} \mathrm{NMR}\left(\mathrm{CDCl}_{3}, 23^{\circ} \mathrm{C}\right): \delta$ 181.2 (CO), 178.9 (CO), 178.6 (CO), 167.8, 165.9 ( $\mathrm{C} \equiv \mathrm{C}-\mathrm{Os}_{3}-$ $(\mathrm{CO})_{8}$ ), 165.5(CO), 80.5 (free $\mathrm{C} \equiv \mathrm{C}$ ) , 52.6, 48.6, 34.4, 32.4, 28.7, 27.5, 26.4, $18.2\left(\mathrm{CH}_{2}\right)$. Anal. Calcd for $\mathrm{C}_{58} \mathrm{H}_{60} \mathrm{O}_{16} \mathrm{Os}_{6}$ : C, 32.31; $\mathrm{H}, 2.79$. Found: $\mathrm{C}, 32.52 ; \mathrm{H}, 2.79$.

Preparation of 5 from 1 and 4. Compound $\mathbf{1}$ (10 mg, 0.01 mmol) was dissolved in $\mathrm{CH}_{2} \mathrm{Cl}_{2}(5 \mathrm{~mL})$, and a solution of $\mathrm{Me}_{3}$ $\mathrm{NO}$ (1.5 mg, $0.02 \mathrm{mmol}$ ) in MeCN (2 mL) was added over $1 \mathrm{~h}$. The solution was stirred for another $3 \mathrm{~h}$ at ambient temperature. Compound 4 (17 mg, $0.015 \mathrm{mmol}$ ) was added into the solution, and the resulting mixture was stirred for $2 \mathrm{~h}$. The solvent was removed on a rotary evaporator, and the residue separated by TLC. Compound $\mathbf{5}$ (4 mg, 19\%) was obtained from the second yellow band, and the unconsumed 4 (5 mg) was recovered from the first yellow band.

Preparation of $\mathbf{6}$ from $\mathbf{2}$ and $\mathbf{C}_{\mathbf{1 4}} \mathbf{H}_{\mathbf{2 0}}$. This reaction was carried out in an ACE microscale photoreaction vessel equipped with an immersed Pen-Ray 5.5 W low-pressure, cold cathode, mercury gaseous discharge lamp. Compound 2 (50 mg, 0.026 $\mathrm{mmol})$ and $\mathrm{C}_{14} \mathrm{H}_{20}(65 \mathrm{mg}, 0.35 \mathrm{mmol}$ ) were dissolved in THF $(35 \mathrm{~mL})$. The mixture was irradiated for $2.5 \mathrm{~h}$ with dinitrogen slowly bubbling through the solution. The solvent was removed on a rotary evaporator, and the residue was subjected to TLC, el uting with $\mathrm{CH}_{2} \mathrm{Cl}_{2} / \mathrm{n}$-hexane $(1: 4, \mathrm{v} / \mathrm{v})$. Two blue bands were isol ated to give $6 \mathbf{a}$ (5 mg, 9\%) and $6 \mathbf{b}(5 \mathrm{mg}, 9 \%)$, which have the same chemical formula of $\left(\mathrm{Os}_{3}(\mathrm{CO})_{9}\right)_{2}\left(\mu, \mu-\eta,{ }^{4} \eta^{4}-\left(\mathrm{C}_{14} \mathrm{H}_{20}\right)_{3}\right)$.

Characterization of 6a. Mass spectrum (FAB): $\mathrm{m} / \mathrm{z} 2212$. IR ( $\left.\mathrm{CH}_{2} \mathrm{Cl}_{2}, v \mathrm{CO}\right): 2100$ (m), 2048 (vs), 2012 (sh), 1998 (vs), $1964(\mathrm{~s}), 1916(\mathrm{~m}) \mathrm{cm}^{-1} .{ }^{1} \mathrm{H}$ NMR $\left(\mathrm{C}_{6} \mathrm{D}_{6}, 23^{\circ} \mathrm{C}\right): \delta 3.47(\mathrm{~m})$, $3.36(\mathrm{~m}), 3.23(\mathrm{~m}), 3.09(\mathrm{~m}), 2.93(\mathrm{~m}), 2.57(\mathrm{~m}), 2.32(\mathrm{~m}), 2.21-$ $0.90(\mathrm{~m}) .{ }^{13} \mathrm{C}\left\{{ }^{1} \mathrm{H}\right\}$ NMR $\left(\mathrm{C}_{6} \mathrm{D}_{6}, 23^{\circ} \mathrm{C}\right): \delta 177.9,176.1,176.0$ (CO), 175.8, 161.8, 130.8, 127.1 ( $\mu$ - $\mathrm{C}_{4} \mathrm{Os}$ ), 82.5, 80.1 (free $\mathrm{C} \equiv$ C), 44.8, 42.9, 36.4, 34.0, 32.8, 31.6, 31.1, 30.6, 29.9, 28.8, 28.3, 27.5, 26.7, 25.0, 19.5, $17.7\left(\mathrm{CH}_{2}\right)$.

Characterization of $\mathbf{6 b}$. Mass spectrum (FAB): $\mathrm{m} / \mathrm{z} 2212$. IR $\left(\mathrm{CH}_{2} \mathrm{Cl}_{2}, v \mathrm{CO}\right): 2100$ (m), 2048 (vs), 2012 (sh), 1998 (vs), 


\section{Chart 1}
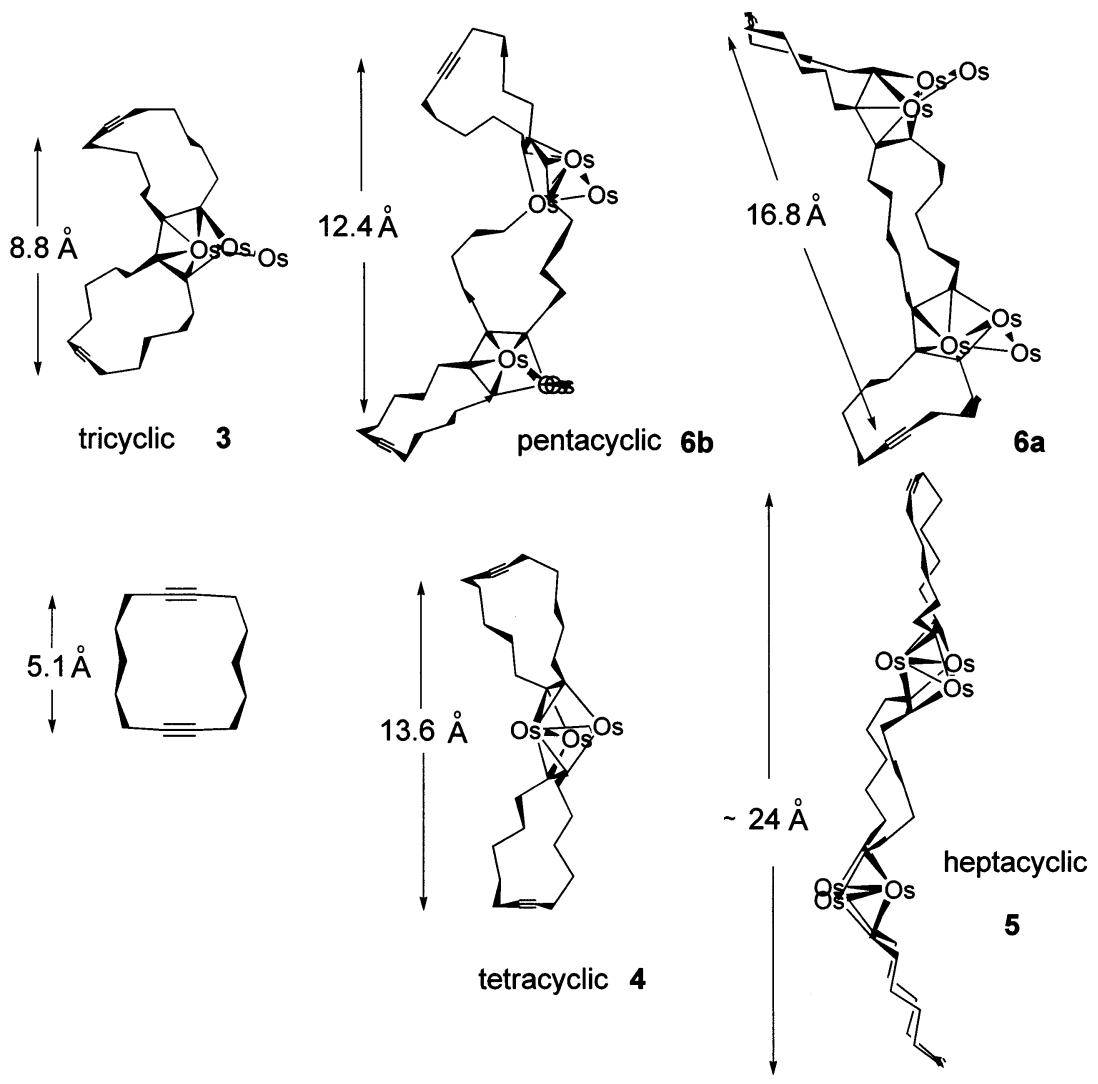

$1964(\mathrm{~s}), 1916(\mathrm{~m}) \mathrm{cm}^{-1} .{ }^{1} \mathrm{H}$ NMR $\left(\mathrm{CD}_{2} \mathrm{Cl}_{2}, 23^{\circ} \mathrm{C}\right): \delta 3.29(\mathrm{~m})$, $3.05(\mathrm{~m}), 2.84(\mathrm{~m}), 2.61(\mathrm{~m}), 2.45(\mathrm{~m}), 2.32(\mathrm{~m}), 2.22(\mathrm{~m}), 2.14-$ $0.85(\mathrm{~m}) .{ }^{13} \mathrm{C}\left\{{ }^{1} \mathrm{H}\right\}$ NMR $\left(\mathrm{CD}_{2} \mathrm{Cl}_{2}, 23{ }^{\circ} \mathrm{C}\right): \delta 178.0,176.1,175.9$ (CO), 175.8, 161.4, 130.5, 127.1 ( $\mu$-C 4 Os), 82.1, 80.2 (free $\mathrm{C} \equiv$ C), 44.7, 42.3, 36.0, 33.6, 32.2, 31.4, 31.1, 29.4, 28.7, 28.5, 27.7, 26.7, 25.3, 19.3, $17.6\left(\mathrm{CH}_{2}\right)$.

Preparation of 6 from 1 and 3. This reaction was carried out in the same vessel described above. Compounds $\mathbf{1}(20 \mathrm{mg}$, $0.019 \mathrm{mmol}$ ) and 3 (23 $\mathrm{mg}, 0.019 \mathrm{mmol}$ ) were dissolved in $\mathrm{n}$-hexane $(20 \mathrm{~mL})$. The mixture was irradiated for $2.5 \mathrm{~h}$ with dinitrogen slowly bubbling through the solution. The solvent was removed on a rotary evaporator, and the residue separated by TLC. Compounds $\mathbf{6 a}(3 \mathrm{mg}, 7 \%)$ and $\mathbf{6 b}(3 \mathrm{mg})$ were obtained.

Structure Determination for $4,6 a$, and $\mathbf{6 b}$. The crystals of $\mathbf{4}, \mathbf{6 a}$, and $\mathbf{6 b}$ found suitable for X-ray analysis were each mounted in a thin-walled glass capillary and aligned on Nonius CAD-4 (for 4) and Bruker Smart ApexCCD (for $\mathbf{6 a}$ and $\mathbf{6 b}$ ) diffractometers with graphite-monochromated Mo K $\alpha$ radiation $(\lambda=0.71073 \AA)$. The $\theta$ range for data collection was $1.41-$ $27.50^{\circ}$ for $\mathbf{4}, 1.22-27.50^{\circ}$ for $\mathbf{6 a}$, and $1.09-27.50^{\circ}$ for $\mathbf{6 b}$. Of the 9721, 37 903, and 57997 reflections collected for $\mathbf{4}, \mathbf{6 a}$, and $\mathbf{6 b}, 9721,15$ 690, and 16011 reflections were independent, respectively. All data were corrected for Lorentz and polarization effects and for the effects of absorption. The structure was solved by the direct method and refined by least-squares cycles. The non-hydrogen atoms were refined anisotropically. Hydrogen atoms were included but not refined. All calculations were performed using the SHELXTL-97 package. ${ }^{15}$ The data collection and refinement parameters are presented in Table 1.

Acknowledgment. We are grateful for support of this work by the National Science Council of Taiwan.

Supporting I nformation Available: Complete tables of crystallographic data, positional parameters, anisotropic thermal parameters, bond angles, bond distances, and torsion angles of $\mathbf{4 , 6 a}$, and $\mathbf{6 b}$. This material is available free of charge via the Internet at http://pubs.acs.org.

\section{OM030179X}

(15) Sheldrick, G. M. SHELXTL-97, Program for crystal structure refinement; University of Göttingen: Germany, 1997. 